
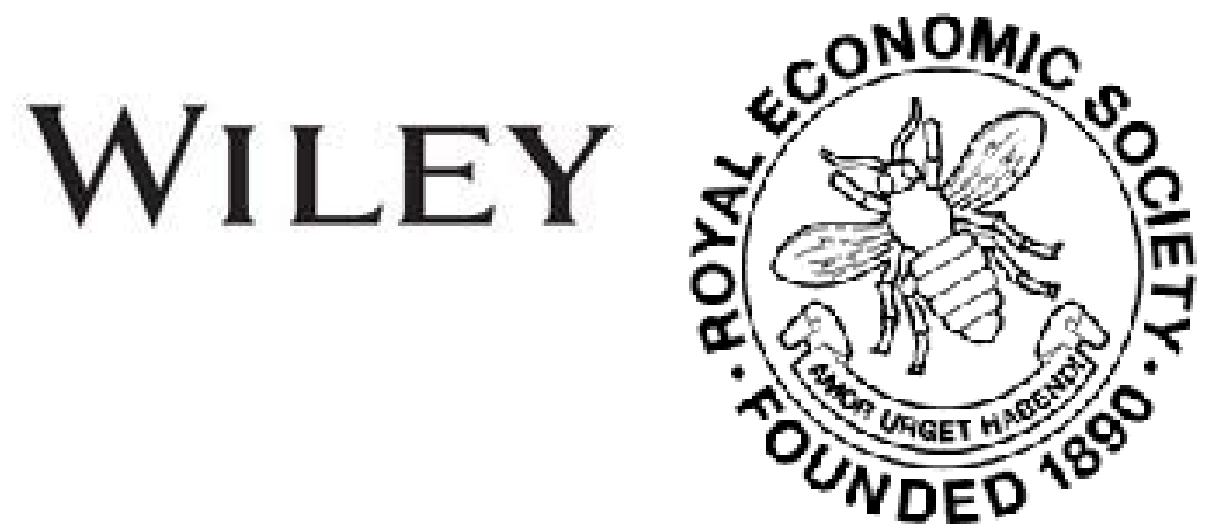

The Rehabilitation of Ricardo

Author(s): W. J. Ashley

Source: The Economic Journal, Vol. 1, No. 3 (Sep., 1891), pp. 474-489

Published by: Wiley on behalf of the Royal Economic Society

Stable URL: http://www.jstor.org/stable/2956112

Accessed: 27-06-2016 10:22 UTC

Your use of the JSTOR archive indicates your acceptance of the Terms \& Conditions of Use, available at

http://about.jstor.org/terms

JSTOR is a not-for-profit service that helps scholars, researchers, and students discover, use, and build upon a wide range of content in a trusted digital archive. We use information technology and tools to increase productivity and facilitate new forms of scholarship. For more information about JSTOR, please contact support@jstor.org.

Wiley, Royal Economic Society are collaborating with JSTOR to digitize, preserve and extend access to The Economic Journal 


\section{THE REHABILITATION OF RICARDO}

In the development of the mental sciences exegesis has frequently played an important part. A change of doctrine has been justified, or supported, or commended for general acceptance, by a new interpretation of an authoritative text. Sir Henry Maine has explained the nature of this process in the history of Roman Law :-

The authors of the new jurisprudence during the whole progress of its formation professed the most sedulous respect for the letter of the Code. They were merely explaining it, deciphering it, bringing out its full meaning; but then, in the result, by piecing texts together, by adjusting the law to states of fact which actually presented themselves, and by speculating on its possible application to others which might occur, by introducing principles of interpretation derived from the exegesis of other written documents ... they educed a vast variety of canons which had never been dreamt of by the compilers of the Twelve Tables, and which were in truth rarely or never to be found there. ${ }^{1}$

We are all of us able to supply examples for ourselves of a similar procedure in theology.

There are not wanting indications that something of the same. kind is now taking place in English Political Economy with reference to Ricardo. It is a comparatively recent and an almost exclusively English phenomenon. To say nothing of the historical economists, the re-creator of abstract economics in England, Stanley Jevons, did not hesitate twelve years ago to describe Ricardo as an 'able but wrong-headed man,' who had 'shunted the car of economic science on to a wrong line ' ${ }^{2}$ while, within the last few months, the spokesman of the new Austrian abstract school has declared, without any words of qualification, that

${ }^{1}$ Ancient Law, p. 34.

? Preface to 2 nd ed. of his Theory, p. lvii. 
Ricardo's fundamental position is, ' as every one to-day knows,' simply 'false.' 1

But to certain recent English writers such sweeping condemnation as this is distasteful. They think that it is possible to combine a profound reverence for Ricardo with the acceptance of all that is valuable in the work of later teachers. Not that they always take up the same line of defence. Sometimes it is maintained that many of the dogmas of Ricardo and his chief followers 'were originally put forward not at all as independent truths, but as the outcome of particular illustrations of a scientific method of inquiry.' It is conceded that this 'was not quite clear' to Ricardo and his followers themselves, and that 'they did not make their drift obvious;' so that it would seem to be dealing hard measure to those unfortunate persons who 'misapplied' such dogmas to dismiss them as 'sciolists.' ${ }^{2}$ But more frequently it is held that these dogmas, or 'many' of the more 'characteristic of them,' are truths when properly understood. What they need is merely to be 'supplemented,' and 'stated with proper qualifications and reserves.' 3 ' Ricardo did not, in interpreting his results, take the precautions necessary to provide against misconceptions on the part of many of his readers.' 4 'He made short cuts'; ' he did not state explicitly what he was doing'; ' his reticence was an error of judgment'; 'if we desire to understand him, we must interpret him generously.' ${ }^{5}$ Interpreted generously, qualified and supplemented, his teaching is still of permanent value.

This attitude is a very natural one. English economists can hardly fail to be proud of Ricardo; and whether their pride takes the form of treating him as an Angel of Light or as the Prince of Darkness, they will probably all assign to him much greater influence than foreign economists would allow. Besides, if, as we are told, it is a pleasure to the young and vehement to be heterodox and to scoff at great names, it is a comfort to the staid and academic 'stare super antiquas vias,' to feel that they are building on the foundations that were laid by the fathers of their church.

Yet such a frame of mind is not without its dangers. The 'Responsa Prudentum' doubtless kept up the popular respect for

${ }^{1}$ Dr. Böhm-Bawerk in Annals of the American Academy of Political Science, p. 252. [Oct. 1890.]

2 Marshall, Present Position of Economics, $\$ 7$.

3 Sidgwick, Principles, p. 10.

${ }^{4}$ Keynes, Scope and Method of Political Economy, p. 5.

5 Marshall, Principles, pp. 530-532. 
the Twelve Tables, while they assisted in the creation of an enlightened jurisprudence; but they must often have unintentionally given a misleading impression of what the Twelve Tables originally meant. And it is because it seems to me that the great treatise of Professor Marshall is not altogether faultless in this respect that I venture to criticise some examples of his exegesis.

Professor Marshall has an excursus of eight pages ${ }^{1}$ on 'Ricardo's theory of Cost of Production in relation to Value.' It begins as follows :-

Ricardo's theory of cost of production in relation to value occupies so important a place in the history of economics that any misunderstanding as to its real character must necessarily be very mischievous. . . . There is a widely spread belief that it has needed to be reconstructed by the present generation of economists. The purpose of the present note is to show cause for not accepting this opinion; and for holding, on the contrary, that the foundations of the theory as they were left by Ricardo remain intact.

His argument is chiefly directed against the supposition that the Jevonsian or Austrian doctrine of utility is inconsistent with that of cost of production, - as laid down, for instance, by J. S. Mill in one of his two expositions of it, ${ }^{2}$ and as stated and criticised by Professor Sidgwick. ${ }^{3}$ Here Professor Marshall would seem to be in the right, if one who has no gift for the use of the abstract 'organon' can have an opinion. But there is the prior task of showing that what has come to be known as the Ricardian doctrine of cost of production was the doctrine of Ricardo; and here Professor Marshall is scarcely so successful. It is a point that deserves some attention; for Professor Marshall is pained to think that Rodbertus and Karl Marx should 'claim Ricardo's authority for the statement that the natural value of things consists solely of the labour spent on them;' and in a later passage he refers confidently to this note as proving that this 'premiss' of theirs is 'really as opposed to the general tenor of Ricardo's theory of value as it is to common sense.' ${ }^{4}$ This is the first proposition I would like to criticise.

Professor Marshall's argument rests on those sections $(4,5)$ of Ricardo's first chapter where he recognises that his principle that 'the quantity of labour bestowed on the production of commo-

1 Pp. 529 seq.

${ }^{3}$ Bk. ii. ch. ii. $\S 2.9$.
${ }^{2}$ Bk. iii. ch. iv. $\S 4$.

${ }^{4}$ P. 619. 
dities regulates their relative value' is ' considerably modified by the employment of machinery and other fixed and durable capital ;' as well as by its ' unequal durability and by the unequal rapidity with which it is returned to its employer.' 1 It may be observed, indeed, that even in his exegesis of these sections our author seems to go beyond what is written; for he attributes to Ricardo the opinion that his principle would be modified by differences in the amount of capital, ${ }^{2}$ whereas all Ricardo considers is the proportion of fixed capital, and the rapidity with which capital returns. The argument from these sections is further supported by a reference to the note in the third edition, where Ricardo expressly declares that in ' cost of production' he includes profit.

It is not necessary for the present purpose to discuss the exact effect of these 'modifications' upon his general doctrine, or what precisely he meant by ' considerably modified.' But it is right to lay stress on the following facts:-

(1) That Ricardo did not think these modifications touched the essence of his doctrine; and that he continued to lay it down in terms indistinguishable from those employed by Rodbertus and Marx;

(2) That he was understood in this sense by all his most influential followers and exponents ;

(3) That his doctrine rested, at least in part, upon an identification of capital with labour, and of profits with return for labour, which was afterwards worked out by his followers, and which also entered into the later Socialist theory. Let me illustrate each of these points by a few quotations.

(1) As to Ricardo's own statement of the doctrine :-

This (i.e. labour) is really the foundation of the ex"changeable value of all things. . . . ${ }^{3}$

If the quantity of labour realised in commodities regulates their exchangeable value, etc. ${ }^{*}$ [Is not Marx merely using more forcible language for the same meaning when he speaks of values as 'crystals' or 'congelations' of the common social substance, labour? Cf. Ricardo's use of the phrase in other passages: 'The comparative value of the fish and the game would be entirely regulated by the quantity of labour realised in each.' ${ }^{5}$ ]

Apropos of his argument as to different qualities of labour, he

${ }^{1}$ Quoted from the headings to the sections in the third and subsequent editions.

2 'If it was assisted by more capital,' p. 532.

${ }^{3}$ P. 10 in the edition ordinarily used, the reprint of the third edition.

4 P. 11.

${ }^{5}$ P. 18 (in one of the additions to the 1st edition). 
quotes from Adam Smith: "There may be more labour in an hour's hard work than in two hours' easy business; or in an hour's application to a trade, which it costs ten years' labour to learn, than in a month's industry at an ordinary and obvious employment.' 1 [Is not this Marx's 'reduction of all kinds of actual labour to their common character'? Cf. Jevons: 'Ricardo by a violent assumption, founded his theory of value on quantities of labour considered as one uniform thing.' 2 ]

Though Adam Smith fully recognised the principle ... he limits its application to 'that rude and early state of society, etc. ... as if, when profits and rent were to be paid, they would have some influence on the relative value of commodities, independent of the mere quantity of labour that was necessary to their production. ${ }^{3}$ [Does this not imply that in Ricardo's opinion the necessity of paying profits would have no such influence?]

And finally, after all his modifications, he returns to his principle at the beginning of Chapter IV. :-

In making labour the foundation of the value of commodities, and the comparative quantity of labour which is necessary to their production the rule which determines the respective quantities of goods which shall be given in exchange for each other, we must not be supposed to deny the accidental deviations. . . .

(2) As to the sense in which Ricardo was understood by his disciples :-

1821. James Mill: The exchangeable value of all commodities is determined by quantity of labour. ${ }^{4}$

1824. De Quincey: The ground of the value of all things lies in the quantity of labour which produces them. ${ }^{5}$

1824. McCulloch: The fundamental principle maintained by Mr. Ricardo is that the exchangeable value of commodities depends exclusively on the quantities of labour necessarily required to produce them. ${ }^{6}$

1827. To these may be added the opinion of Malthus: $\mathrm{He}$ (Ricardo) has not confined himself to the assertion that what he calls the value of a commodity is determined by the quantity of labour worked up in it; but he states in substance the following

1 P. 15 , note.

2 Theory, p. 179.

${ }^{3}$ P. 16 in 1st ed. ; omitted in 3rd and later editions.

4 In 3rd ed., 1826, p. 97.

5 The Templars' Dialogues, in Works, iv. 190 [ed. 1863].

${ }^{6}$ Discourse on the Rise, etc., of Pol. Econ., 1824, p. 66. This sentence, in accordance with McCulloch's amusing habit, is repeated verbatim in his Life of Ricardo prefixed to his Works; and doubtless in many other places in McCulloch's writings. 
proposition, that commodities exchange with each other according to the quantity of manual labour worked up in them. . . . Mr. Ricardo, indeed, admits of considerable exceptions to his rule. ... Yet notwithstanding these admissions, he proceeds with his rule as if there hat been few or no exceptions to it. ${ }^{1}$

(3) But by 'labour' Ricardo did not mean only that labour which has been immediately occupied upon the manufacture of a particular article. The term covers all the labour that has indirectly as well as directly contributed to the product, including all that has been devoted to the creation of the capital with which the process may have been assisted.

Their comparative prices [in the case of the beaver and deer] would be in proportion to the actual labour bestowed, both on the formation of the capital and on the destruction of the animals. ${ }^{2}$

If we suppose the occupations of the society extended . . . still the same principle would hold true, that the exchangeable value of the commodities produced would be in proportion to the labour bestowed on their production; not on their immediate production only, but on all those implements or machines required to give effect to the ... labour. ... ${ }^{3}$

The clearest exposition of this view is to be found in James Mill, who sums it up in the two propositions that 'Capital is hoarded labour,' and that 'Profits are simply remuneration for' labour.' ' His illustration from machinery is especially significant, as showing the way in which the doctrines of the Ricardian school suggested the later Socialist formulation:

A man has a machine, the produce of 100 days' labour. In applying it, the owner undoubtedly applies labour, though in a secondary sense, by applying that which could not have been had but through the medium of labour. This machine, let us suppose, is calculated to last exactly ten years. One-tenth of the fruits of 100 days' labour is thus expended every year; which is the same thing in the view of cost and value, as saying that 10 days' labour have been expended. The owner is to be paid for the 100 days' labour which the machine cost him, at the rate of so much per annum, that is by an annuity for ten years, equivalent to the original value of the machine. ${ }^{5}$

Marx says exactly the same; though his application is different.

1 Definitions, pp. 26-27.

2 P. 16.

3 P. 17.

+ Elements, ch. iii. sect. ii.

s Ibid. p. 103. 
However useful a given kind of raw material, or a machine, or other means of production may be, though it may cost $£ 150$ or, say, 500 days' labour, yet it cannot under any circumstances add to the value of the product more than $£ 150 .^{1}$

The key, then, to the difficulty as to Ricardo's meaning is apparently this. When he laid down that value depended altogether on the quantity of labour, he included in that quantity all the labour that had gone to the production of all the capital in its various forms with which the manual toil was assisted. $\mathrm{He}$ would therefore not have used such a phrase as Professor Marshall's, that values are 'proportionate to the amount of labour required only on condition . . . that it is assisted by proportionate amounts of capital '; ${ }^{2}$ because that treats Capital as a separate element in production alongside of Labour, while he included Capital in Labour as merely another form of the one great force. This might seem at first sight only another phraseology for the same view, a difference between Tweedledum and Tweedledee. But the mischief lay in what seemed to be suggested by Ricardo's formula; namely, that as all the contributions towards production were of the same nature, the shares justly assignable to each out of the resulting value must be determined by the same principle. Hence the contribution towards production of the capitalist-employer must be either his direct labour, which could be remunerated on the same scale as that of any other manager, or the stored-up labour (i.e. capital) which contributed just itself and therefore could claim only to be replaced. True, Ricardo did not draw this conclusion himself. Profits, according to him, are (not, as they should be on his general principle, determined by the same law as wages, but) what remains from value after wages are taken out. Moreover, he regarded the payment of interest, i.e. of something more than the mere replacement of the capital, as a matter of course. In one sense, therefore, it is true that the Socialists cannot justly claim him as their authority; for he assumed as self-evident the continuance of certain parts of the modern distributive process which they reject. But in another and more important sense they can; for they can fairly maintain that in his theory of the production of value he furnishes them with a test wherewith to disprove the justice of the modern system of distribution. This is recognised by a writer so unsympathetic to the Socialists

${ }^{1}$ Capital, ch. viii. Engl. trans. p. 188; cf. pp. 383-4. Cf. as to 'the English' or 'Ricardian view,' Roscher, Pol. Econ. Engl. trans. i. 167, n. 6 ; 319, n. 3.

2 P. 532. 
as Dr. Böhm-Bawerk. 'It was the development and popularising of the Ricardian theory of value which supplied the scientific soil, out of which the Exploitation theory could naturally spring and grow.' 1

In order that Ricardo should be altogether freed from the reproach of giving any countenance to Socialist doctrines, it is necessary to go further, and to argue that he did not teach ' the iron law of wages.' This Professor Marshall does in the following passage :

Ricardo's language was even more unguarded than that of Adam Smith and Malthus. It is true, indeed, that he said distinctly:- ' It is not to be understood that the natural price of labour estimated in food and necessaries is absolutely fixed and eonstant. . . . It essentially depends on the habits and customs of the people.' But, having said this once, he did not take the trouble to repeat it constantly; and most of his readers forget that he ever said it. In the course of his argument he frequently adopted a mode of speaking similar to that of the Physiocrats; and seemed to imply that the tendency of population to increase rapidly as soon as wages rise above the bare necessaries of life, causes wages to be fixed by ' a natural law' to the level of those bare necessaries. This law has been called, especially in Germany, Ricardo's 'iron ' or 'brazen ' law : many German Socialists believe that this law is in operation now . . . and they claim Ricardo as an authority on their side.

In fact, however, Ricardo was not only aware that the necessary or natural limit of wages was fixed by no iron law, but is determined by the local conditions and habits of each place and time: he was further keenly sensitive to the importance of a higher 'standard of living,' and called on the friends of humanity to exert themselves to encourage the growth of a resolve among the working classes not to allow their wages to fall anywhere near the bare necessaries of life (my italics). ${ }^{2}$

This very strong assertion is supported in a footnote by the quotation of a certain passage from Ricardo's fifth chapter. Professor Marshall evidently attaches great weight to this particular passage; in a note on the next page he expresses his surprise that it should have escaped the attention of J. S. Mill. But, on examining the passage in question, it will be found that it does not appear in Ricardo's first edition, and that it is by no means certain that it means quite all Professor Marshall gets out

${ }^{1}$ Capital and Interest, Eng. trans. p. 317. Cf. pp. 316, 329, 366, et passim.

${ }^{3}$ P. 553.

No. 3.- -voL. I 
of it. As the point is of some interest, it may be worth while quoting at length the parallel passages in the earlier and later versions. In all the editions, the paragraph in which the passages occur begins as follows :-

In those countries where there is abundance of fertile land, but where from the ignorance, indolence, and barbarism of the inhabitants, they are exposed to all the evils of want and famine, and where it has been said that population presses against the means of subsistence, a very different remedy should be applied from that which is necessary in long-settled countries, where from the diminishing rate of the supply of raw produce all the evils of a crowded population are experienced. In the one case, the misery proceeds from the inactivity of the people. To be made happier they need only to be stimulated to exertion; with such exertion, no increase in the population can be too great as the powers of production are still greater. In the other case, the population increases faster than the funds required for its support. Every exertion of industry, unless accompanied by a diminished rate of increase in the population, will add to the evil, for production cannot keep pace with it.

\section{Then comes, in the first edition, the following passage :-}

In some countries of Europe, and many of Asia, as well as in the islands in the South Seas, the people are miserable, either from a vicious government or from habits of indolence, which make them prefer present ease and inactivity, though without security against want, to a moderate degree of exertion, with plenty of food and necessaries. By diminishing their population, no relief would be afforded, for production would diminish in as great or even in a greater proportion. The remedy for the evils under which Poland and Ireland suffer, which are similar to those experienced in the South Seas, is to stimulate exertion, to create new wants and to implant new tastes, for these countries must accumulate a much larger amount of capital, before the diminished rate of production will render the progress of capital necessarily less rapid than the progress of population. The facility with which the wants of the Irish are supplied, permits that people to pass a great part of their time in idleness: if the population were diminished, the evil would increase, because wages would rise, and therefore the labourer would be enabled, in exchange for a still less portion of his labour, to obtain all that his moderate wants require.

Give to the Irish labourer a taste for the comforts and enjoyments which habit has made essenticl to the English labourer, and he would be then content to devote a further portion of his time to 
industry, that he might be enabled to obtain them. Not only would all the food now produced be obtained, but a vast additional value in those other commodities to the production of which the now unemployed labour of the country might be directed.

This is replaced, in the third edition, by these sentences :-

With a population pressing against the means of subsistence, the only remedies are either a reduction of people, or a more rapid accumulation of capital. In rich countries, where all the fertile land is already cultivated, the latter remedy is neither very practicable nor very desirable, because its effects would be, if pushed very far, to render all classes equally poor. But in poor countries, where there are abundant means of production in store, from fertile land not yet brought into cultivation, it is the only safe and efficacious means of removing the evil, particularly as its effect would be to elevate all classes of the people.

The friends of humanity cannot but wish that in all countries the labouring. classes should have a taste for comforts and enjoyments, and that they should be stimulated by all legal means in their exertions to procure them. There cannot be a better security against a superabundant population.

And then, in all editions, the argument thus runs on :-

In those countries, where the labouring classes have the fewest wants, and are contented with the cheapest food, the people are exposed to the greatest vicissitudes and miseries. They have no place of refuge from calamity; they cannot seek safety in a lower station ; they are already so low that they can fall no lower. On any deficiency of the chief article of their subsistence, there are few substitutes of which they can avail themselves, and dearth to them is attended with almost all the evils of famine. ${ }^{1}$

The passage quoted by Professor Marshall is that beginning with 'The friends of humanity,' and ending with 'the evils of famine.' But, on comparing the two texts, though it will be recognised that it is just possible that in the later Ricardo may have intended to soften his teaching, and have thrust in a sentence without any regard to the argument of the page, it would seem much more probable that the later version is only another way of stating the earlier. He had been distinguishing between 'rich' and 'poor' countries: for the latter, but not for the former, the remedy for distress is to induce the people to be more industrious. In the first edition he had cited as examples

${ }^{1}$ First edition, pp. 99 102; usual edition, pp. 55-54. 
of poor countries Poland and Ireland. In the case of the Irish, he had remarked that, could they but be given a taste for comforts, they would certainly work harder. In the third edition these specific examples are left out; instead, he repeats his distinction between 'rich' and 'poor' countries; and, in spite of the phrase 'all countries,' the context would imply, just as in the first edition, that to stimulate the desire for comforts is the remedy peculiarly suitable to poor lands. If this is his meaning, the phrase 'exertions to procure them' in the later edition is intended to correspond with 'devote a further portion of his time to industry, that he might be enabled to obtain them' in the earlier. The one remedy, in brief, for poor countries, is greater industry. This is probably, on the whole, what Ricardo intended to say. Even if the phrase 'all countries' suggests a wider application, the impression from the whole argument, it may fairly be urged, is very different from that given by Professor Marshall's. language about ' not allowing their wages to fall.'

Looking at Ricardo's chapter on wages as a whole, and his subsequent teaching as to the incidence of taxation, it does not seem difficult to get at his meaning. He recognises that there are differences in the 'standard of living' as between different nations and different ages. He thinks it desirable that this standard should be raised; but he believes that in 'rich' and 'longsettled' countries the only way to bring this about is ' a reduction of people.' And, although the standard of comfort in England was comparatively high, as compared, for instance, with that of Ireland, and included 'moderate comforts' and 'conveniences,' yet he constantly implies that these comforts are but little above the physical minimum.

Wages would fall if they were regulated only by the supply and demand of labourers; but we must not forget that wages are also regulated by the prices of the commodities on which they are expended. As population increases, these necessaries will be constantly rising in price. . . . If then the money wages of labour should fall, whilst every commodity on which the wages of labour were expended rose, the labourer would be doubly affected, and would be soon totally deprived of subsistence. ${ }^{1}$

This theory as to the relation of wages to subsistence was fruitful in consequences. It led directly to some of Ricardo's most important doctrines; - that, as the cost of food, and therefore wages, tended to increase, profits tended to diminish; and that

1 P. 54. 
taxes, either on wages or on raw produce, were taxes on profits. In his formal argument for these conclusions, he does indeed introduce 'qualifications' almost sufficient to satisfy even his recent exponents :

A tax on raw produce and on the necessaries of the labourer, would have another effect, it would raise wages. From the effect of the principle of population on the increase of mankind, wages of the lowest kind never continue much above that rate which nature and habit demand for the support of the labourers. This class is never able to bear any considerable portion of taxation; and consequently, if they had to pay 8s. per quarter in addition for wheat, and in some smaller proportion for other necessaries, they would not be able to subsist on the same wages as before, and to keep up the race of labourers. Wages would inevitably and necessarily rise. ${ }^{1}$

But though he sometimes guards himself in his formal argument, in his subsequent statement he constantly speaks as if the result would certainly follow in the case of the great mass of labourers. Thus :-

Wages invariably rise with the rise in raw produce. ${ }^{2}$

Taxes on wages will raise wages. ${ }^{3}$

Diminish the cost of subsistence of men, by diminishing the natural price of the food and clothing by which life is sustained, and wages will ultimately fall. ${ }^{4}$

The champions of Ricardo have, of course, one final refuge in the phrase 'nature and habit.' They may observe that the standard of living might be very high, indeed luxurious; but that it might be so endeared to the labourers by custom, that if any encroachment were made upon it by taxation, their rate of multiplication would slacken to such a degree as to throw the burden on the employers. But it is difficult to believe that Ricardo contemplated such a possibility. What he intended to teach the world, James Mill surely knew if any one did. And here is James Mill's version of it:-

If wages are already at the lowest point to which they can be reduced; that is just sufficient to keep up the number of labourers and no more; a state of wages which seems to have been contemplated by Mr. Ricardo throughout his disquisitions on Political Economy, and which the tendency of population to increase faster
1 P. 93.
2 P. 63.
3 P. 129.
4 P. 232. 
than capital undoubtedly leads us to regard as the natural state no tax can fall upon the labourer. ${ }^{1}$

Can we not say that, although Ricardo concedes the bare possibility of a rise in the standard of living, the possibility is, in his mind, not sufficiently strong to influence the course of his subsequent argument; and that, although he recognises that the standard may be already higher in one country than another, he implies that in all it is but little above absolute necessaries, and that this little consists of comforts which in no rhetorical sense have become necessaries? This is the impression he gives not only to Socialists, but also to men like J. S. Mill and Cairnes. ${ }^{2}$ And if it be objected that Mill and Cairnes were misled by traditional misrepresentations, we can turn as before to Ricardo's immediate disciples, and notice how they understood him. I have already quoted the opinion of James Mill. In Mrs. Marcet's Conversations on Political Economy we have an exposition more detailed than usual of what was understood under 'necessaries' by intelligent popularisers of Ricardo's teaching :-

Mrs. B. . . . As the capitalist will always keep wages as low as he can, the labourer and his family can seldom command more than the necessaries of life.

Caroline. By the necessaries of life, do you mean such things only as are indispensably necessary for its support?

Mrs. B. No; I mean such food, clothing, and general accommodation as the climate and custom of the country have rendered essential to the preservation of the life, health, and decent appearance of the lowest classes of the people. Fuel, for example, and warm clothing are necessary articles in this country ; but they are not so in Africa. . . . The use of linen is now considered as necessary by all classes of people, and shoes and stockings, in England at least, almost equally so. Houses with glazed windows and a chimney are become necessaries; for if our poor were deprived of such accommodation it would very materially increase mortality amongst them. ${ }^{3}$

Even with the very lowest standard of living in a country like England something more than food is necessary-shelter and clothing; and an increase in the cost of either shelter or clothing would, therefore, according to Ricardo's theory, send up the rate of wages, just as much as an increase in the cost of food. But.

${ }^{1}$ Elements (ed. 1826), p. 258.

2 On J. S. Mill see Professor Marshall's note already referred to ; on Cairnes, his criticism of Mill in Bain's Life, p. 199.

${ }^{3}$ Conversation VIII. (3rd ed. 1819, p. 122). Cf. also De Quincey, ubi supra, p. 198 ; MeCulloch, Discourse, p. 68. 
Ricardo, as we have seen, very naturally regarded food as so much the larger element that the others could be neglected, and accordingly laid down that wages varied with the cost of food. As to this Professor Marshall has a somewhat obscure note on p. 554. He remarks that-

Prof. Brentano ... gives as a reason for believing that the English classical economists really held the iron law of wages, the fact that they frequently speak of the minimum of wages as depending on the price of corn. But the term ' corn,' as used by them, was short for ' agricultural food products of all kinds.'

This is, of course, true; and for ' corn' Ricardo sometimes substitutes the general term 'provisions.'

The cheapness of provisions.... is after all, whatever intervals we may be willing to allow, the great regulator of the wages of labour. ${ }^{1}$

But how does this disprove Professor Brentano's contention? To argue that the rate of wages depended on the price of provisions surely implied that on the whole wages but barely covered the necessary cost of subsistence. At any rate, this is how the argument was understood by Adam Smith. In seeking to demonstrate that in Great Britain ' the wages of labour do not fluctuate with the price of provisions,' ${ }^{2}$ Adam Smith certainly thought he was presenting an argument against the Physiocrats; and the Physiocrats, as Professor Marshall points out, ${ }^{3}$ held the doctrine of the iron law in a sufficiently rigid form.

There is one more consideration to be noticed, which, although it is not perhaps strictly relevant to Professor Marshall's argument, is essential for a complete view of the case. It is that Lassalle and Karl Marx are themselves careful in their statement of the iron law to explain that wages are not absolutely fixed at the lowest point physically possible. Lassalle assumes, following Ricardo closely in his phraseology, that the standard depends on the habits of the people.

Combien pourrait coûter au marché en moyenne un travailleur, M. Schulze?-Evidemment une somme égale ì l'entretien habituel de tout autre travailleur et de sa famille (Lassalle's italics).

J'ai expliqué au travailleurs que l'entretien nécessaire usuel et conforme aux habitudes du peuple n'était nullement un point fixe

1 Letters, ed. Bonar, p. 34.

2 Bk. i. ch. vii. (ed. Rogers, i. 78).

3 P. 550. 
du salaire de travail ; mais que ce dernier était compris dans une gravitation constante autour de ce point central ; qu'il peut très bien monter pour un temps par suite de la hausse de la demande, mais que par l'accroissement des mariages et du nombre des travailleurs, il retombe toujours à ce point central de l'entretien nécessaire en usage chez le peuple (my italics). ${ }^{1}$

Marx goes further, and anticipates more recent 'historical' conceptions by introducing the idea of historical development:-

His (the labourer's) means of subsistence must therefore be sufficient to maintain him in his normal state as a labouring individual. His natural wants, such as food, clothing, fuel and housing, vary according to the climate and other physical conditions of his country. On the other hand, the number and extent of his so-called necessary wants, as also the modes of satisfying them, are themselves the product of historical development, and depend therefore to a great extent on the degree of civilisation of a country, more particularly on the conditions under which, and consequently on the habits and degree of comfort in which, the class of free labourers has been formed. In contradistinction therefore to the case of other commodities, there enters into the determination of the value of labour-power a historical and moral element. Nevertheless, in a given country, at a given period, the average quantity of the means of subsistence necessary for the labourer is practically known. ${ }^{2}$

Like Ricardo, indeed, Lassalle and Marx frequently speak as if wages were ' fixed to the level of the bare necessaries of life' : and, under the excitement of propaganda, their followers have preached the doctrine in its most unqualified form, much in the same way as the middle-class 'hangers-on and parasites' of the Ricardian school enunciated its doctrines ' without the conditions required to make them true.' ${ }^{3}$ But if in judging the Ricardian school we must go to its founder and interpret him ' generously,' it is clearly none the less desirable to do the same with scientific Socialism. It is surely possible to do this, and yet, like the present writer, to think no better of Socialism because it can fairly claim Ricardo's authority, and to think no worse of Ricardo because his teaching received so unexpected an application.

${ }^{1}$ Capital et Travail, ou M. Bastiat-Schulze (de Delitzch), pp. 231, 316. I have not access to the German original, and therefore quote from the French translation by B. Malon.

2 Capital, ch. vi. Eng. trans. p. 150.

3 Marshall, Principles, p. 63, note 1. 
The Principles of Economics is a work worthy of its author's reputation, and of his position as the doyen of English economists. It casts into the background almost all that has been written in England since John Stuart Mill; it sums up the economic movement of the last forty years, and furnishes the point of departure for a new and fruitful development. It is the more welcome because it brings a message of conciliation to divergent schools, and makes it possible for 'deductive' and 'historical,' 'scientific' and 'ethical' economists to work together in harmony. But it has the defects of its qualities; and one of these defects is illustrated by the passages we have been considering. There are two possible ways of judging a great writer of the past, such as Ricardo. If we wish to form a complete picture of his mind and character we must examine every sentence he has written, and put even a 'generous' construction on his lightest phrase. We may thus learn not only what he succeeded in saying, but what he tried to say; we may drag out the doubts that he managed to overcome; and perhaps, in some cases, save his heart at the expense of his head. But in tracing the growth of economic doctrine we must proceed otherwise. We want to know what was his especial message; what did he himself lay emphasis upon; how was he understood by his contemporaries. Our 'generosity' may find in him charming anticipations of our own ideas; and yet, if it fails to lay stress upon what was really learnt from the teacher by those he immediately influenced, we shall give a false impression. The economic historian, we are told, is apt to be confused in theory; I am afraid we must add that the sympathetic theorist runs the risk of being unhistorical.

W. J. Ashley 